\title{
Why doing Russian and Slavic linguistics matters
}

\author{
Hanne Eckhoff ${ }^{1} \cdot$ Egbert Fortuin $^{2}$. \\ Barbara Sonnenhauser ${ }^{3}$
}

Accepted: 16 February 2021 / Published online: 16 March 2021

(C) The Author(s), under exclusive licence to Springer Nature B.V. part of Springer Nature 2021

With the journal Russian Linguistics entering the third decade of the twentieth century and a new team of editors - assisted by a new editorial board of renowned experts—-taking over, it is a good time to look back and to the future.

During the last decades, Russian Linguistics, edited by the board of Roger Comtet (since 1993), Jos Schaeken (since 1997), Ulrich Schweier (since 2007), and supported by Regina Sippl-Jahn's invaluable assistance in managing the editorial processes (since 2007), has been a top venue for linguistic research on Russian, bringing together linguists and philologists from different traditions and backgrounds. Taking account of the fact that Russian is by no means an isolate but crucially embedded in its family background, in particular (but by no means exclusively) when assuming a diachronic perspective, the scope of the journal has broadened and from 2008 on it explicitly included research on other Slavic languages as well (as attested by its subtitle International Journal for the Study of Russian and other Slavic Languages). Ever since its foundation, Russian Linguistics has had a broad scope of research, from historical linguistics, sociolinguistics, to syntax and semantics. It has been a venue for linguists working in different theoretical frameworks, from descriptive linguistics to cognitive and generative linguistics, pursuing data-driven as well as experimental and theoretically oriented approaches. And during all these times Russian Linguistics has maintained the highest standards, guaranteed by its editors throughout the years (starting with Aleksander Issatschenko, taken over by L'ubomír Ďurovič, André G.F. van Holk and Werner Lehfeldt,

\footnotetext{
B. Sonnenhauser

barbara.sonnenhauser@uzh.ch

H. Eckhoff

hanne.eckhoff@mod-langs.ox.ac.uk

E. Fortuin

E.Fortuin@hum.leidenuniv.nl

1 University of Oxford, Oxford, Great Britain

2 Leiden University, Leiden, The Netherlands

3 University of Zurich, Zurich, Switzerland
} 
continued by Roger Comtet, Jos Schaeken and Ulrich Schweier), its editorial board, and the strongly committed reviewers, whose contribution to maintaining the strictest requirements in terms of scientific quality cannot be overestimated (see also Schweier 2014).

Since the beginning in 1974 (not including the present volume) 597 articles have appeared in Russian Linguistics. In addition, a substantial number of book reviews, discussion pieces, bibliographical surveys and obituaries have been published, bearing witness to the journal's place in the centre of a lively discussion of the linguistic study of Russian. The articles span a wide range of topics, the most popular of which are historical linguistics in a wide sense (173 articles), syntax (148 articles), semantics (128 articles), morphology (96 articles), phonology (61 articles) and aspect (56 articles). The work on syntax comes from a multitude of schools and angles, from Igor' Mel'čuk's Meaning-Text Theory (as in his own "O tipax poverxnostno-sintaksičeskix otnošenij (tri kriterija različenija)", 1977, vol. 3, issues 3-4) to generative grammar (as in Leonard Babby's "Noun phrase internal case agreement in Russian syntax”, 1985, vol. 9, issue 1, or Gilbert Rappaport's 1986 analysis of constructions of the type Mne negde spat' in Russian, vol. 10, issue 1) to corpus-driven construction grammar (as in Laura Janda, Mihail Kopotev and Tore Nesset's "Constructions, their families and their neighborhoods: the case of durak durakom 'a fool times two' ", 2020, vol. 44, issue 2). The work on semantics ranges from Elena Padučeva's many contributions on classical topics in formal semantics (e.g. "Telicity and incremental theme", 2009, vol. 33, issue 2) over Jurij Apresjan's work on lexical semantics (e.g. "Sintaksičeskie priznaki leksem", 1985, vol. 9, issues 2-3) to cognitivist and empirical approaches to semantics in grammar (e.g. Dagmar Divjak's "Mapping between domains. The aspect—modality interaction in Russian", 2009, vol. 33, issue 3). It is no surprise that the most-discussed specialised topic is verbal aspect, which has been up for lively debate since the beginning (e.g. Nikolaj Sal'nikov: "Esče raz o vidovyx parax (glagoly tipa 'nravit'sja' i 'ponravit'sja')", 1975, vol. 2, issues 3-4) and still is (e.g. Jan Patrick Zeller and Christina Clasmeyer: 'Každyj den' turist *otdoxnul na pljaze. An event-related potentials study on the processing of aspectual violation in Russian iterative sentences", 2020, vol. 44, issue 3). And of course, in many of the articles several of these topics intersect. For example, virtually every conceivable aspect of Russian linguistics has been approached from a historical perspective. There is historical morphology (as in Sabine Stoll's article "On the Desinence - $t$ ' of the Early East Slavic imperfect" (2000, vol. 24, issue 3)), historical syntax (as in Emily Klenin's article "On preposition repetition: A study in the history of syntactic government in Old Russian" (1989, vol. 13, issue 3) and Oleg Žolobov's multiple contributions on the history of the morphosyntax of numerals in volumes 26-29), historical phonology (from Alexander Issatschenko's 1979 article “Secondary 'vocalization' of the jers" (vol. 4, issue 2) to Thomas Olander's 2012 article "Proto-Indo-European *-os in Slavic" (vol. 36, issue 3)), and historical semantics, often on the topic of aspect (e.g. Ekaterina Mišina's 2017 article "K izučeniju perfektivnogo imperfekta v drevnerusskom jazyke (v sopostavlenii so staroslavjanskim)", vol. 41, issue 1). Various people have contributed to the study of the Old Novgorod dialect of Russian, or Old Russian in general in Russian Linguistics (such as Henning Andersen, Henrik Birnbaum, Daniel Collins, Aleksej Gippius, Horace Lunt, Jos Schaeken, Andrej Zaliznjak, and many others). Besides the synchronic or diachronic studies of Slavic languages, there have been papers that deal with sociolinguistic topics such as the relation between language and politics (for example Aneta Pavlenko's paper on "Russian in post-Soviet countries" (2008, vol. 32, issue 1)), or with language acquisition (as Maria Polinsky's 2007 article "Reaching the end point and stopping midway: different scenarios in the acquisition of Russian" (vol. 31, issue 2)). In addition, Russian Linguistics has also been a venue for reflecting on the discipline itself, e.g. in Edward Stankiewicz's paper on "The place of J. Baudouin de Courtenay in the history of modern linguistics" (1988, 
vol. 12, issue 2) or the 1996 jubilee issue (vol. 20, issues 1-2), which presents a stocktaking on the development of Russistics in different countries around the globe. Some of the papers which appeared in Russian Linguistics have been highly influential, such as Greville Corbett's "Gender in Russian: An account of gender specification and its relationship to declension" (1982, vol. 6, issue 2). This paper is a cornerstone in the research on grammatical gender in Russian - it is hardly possible to write about Russian gender without acknowledging it. But besides this and other highly influential papers, many more papers published in Russian Linguistics made important contributions to more specialised and therefore smaller circles of Slavic and general linguistics.

The languages of the articles are overwhelmingly English and Russian, even though German and French have been allowed as well. The balance is fairly even: 312 in Russian, 284 in English, 1 in German, but the balance between Russian and English has fluctuated considerably over the years, as seen in the graph shown in Fig. 1.

In later years the balance has slanted towards English, and although we will still accept articles in Russian, we actively encourage submissions in English. There is an inherent value in writing about Russian in Russian, but there is also value in reaching a wider readership, especially since one of the objectives of the journal is to encourage a wide-ranging and open discussion of Russian from a multitude of perspectives, including the perspective from the other Slavonic languages. Choosing English as an overarching lingua franca also allows for the mutual accessibility of theoretical approaches and their fruitful discussions and developments, as evinced e.g. in Elena Padučeva's work on verbal aspect, Barbara Partee and Vladimir Borschev's contributions to formal semantics, Jurij Apresjan's studies in lexicography, and Igor Mel'čuk's work on Russian syntax and semantics. It is only in the last decade that Russian Linguistics has accepted articles that substantially deal with Slavic languages other than Russian and its direct historical precursors (loosely speaking, there have been a good number of articles on Old Novgorodian and Old Church Slavonic from the very beginning). We are convinced that this is something that should be promoted: the closely related Slavic language family is an ideal base for comparison, and the close study of slight variations in syntax, morphology and phonology between the languages can inform the study of

Fig. 1 Language of articles in Russian Linguistics (Russian and English, per cent)

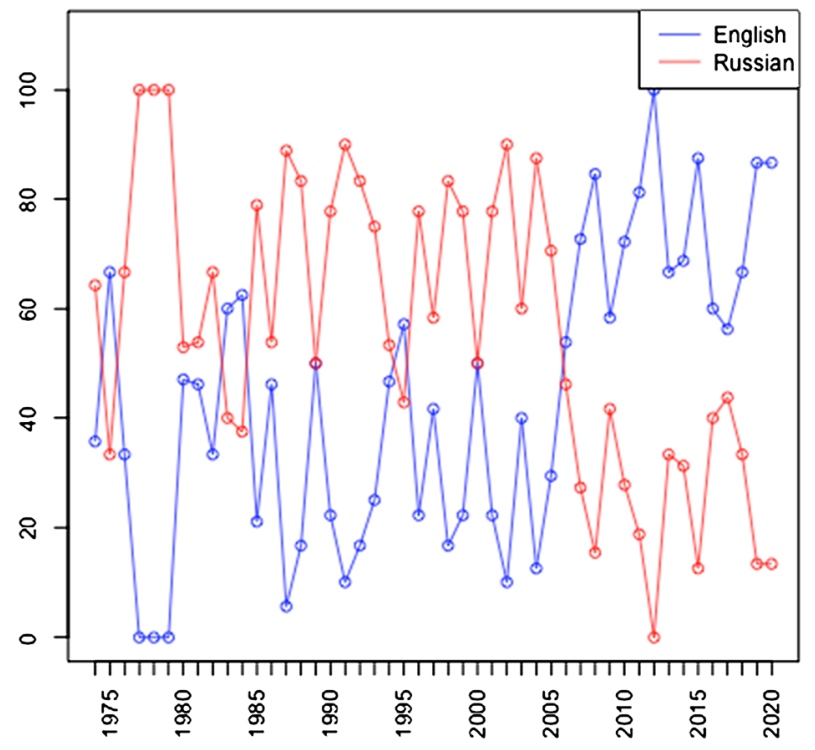


any one of the individual Slavic languages in interesting ways. It is against this background of the mutual relevance of Russian and Slavic linguistics and their contribution to general linguistics, that we have made the choice to explicitly encourage submissions in English.

Since its beginnings in 1974, Russian Linguistics has had a continuing relevance for the linguistic study of Russian and other Slavic languages. While the aim of establishing bridges between linguistic approaches and traditions is as valid in 2021 as it was in 1974, times are changing in other respects, and with this new challenges arise for the editors. Within the academic world the situation for the humanities has sometimes become difficult, and within the humanities the study of topics related to Russia or other Slavic speaking countries has become less obvious. And if we look at research on languages, there is an increasing trend to adopt a general linguistics perspective, stepping away from a language-specific focus. At the same time, Russian and the Slavic languages are often brought forward as relevant data points (and rightly so) to illustrate more general questions, so that familiarity with the peculiarities of those languages is spreading within and across different fields of linguistics. We do think, however, that the study of Russian or other Slavic languages is not only of great importance to general linguistics, but is of vital importance in its own right as well. It is only thanks to in-depth study of specific languages that general trends and properties of language can be studied in the first place. Challenges arise also with the changing status of language as an object of study; it is now increasingly explored with methods from the natural sciences, among them biology and genetics, and is being approached also from an evolutionary perspective at the intersection of cultural and natural history. We strongly believe that the study of Russian and Slavic languages is not only vital for a better understanding of these languages and their cultures in themselves, but also for a better understanding language in general, including its evolutionary underpinnings.

We strongly believe-very much in line with the first editors of Russian Linguistics (see Editorial 1974, p. 1) and in particular its founder Aleksander Issatschenko-that there continues to be a need for a journal dedicated to Russian and the Slavic languages. There is a wealth of intriguing properties of Russian and Slavic languages, attested in their contemporary varieties as well as in older stages, which still awaits study. Just think about the subtleties of meaning conveyed by the inventory of verbal prefixes, the complexities of case assignment and differential argument marking, verbal aspect and its Slavic-internal diversity, word order regularities and the various patterns of clitic placement, the differences in availability of participles across the contemporary varieties and their usage preferences, the various manifestations of subgenders (such as animacy, virility etc.), argument coding patterns, the richness of writing systems and all their cultural implications, the intricate relationships between standard(s) and vernaculars, the impressive number of dialects and the multifaceted contacts among varieties and dialects, the diverse historical developments with their manifold mutual entanglements. Again, in-depth investigations of these peculiar properties make an important contribution to the larger picture of linguistic diversity and thus provide an important point of reference for more generally oriented linguistic studies, from both an empirical perspective and that of linguistic modelling. The increasing availability of larger corpora now allows for quantitative studies (see, e.g. RL's special issue "Corpora and quantitative data in Slavic languages", 2015, vol. 39, issue 3, edited by Neil Bermel), which may reveal patterns that might remain unnoticed otherwise. At the same time, large-scale corpora are not yet available for all Slavic languages, in particular for older stages and non-standard varieties, and various efforts are currently under way to remedy this gap. These efforts range from the extensive ecosystems around the large national corpora such as the Russian National Corpus and the Czech National Corpus to parallel corpora such as the Parallel corpus of Slavic and 
other languages PARASOL, ${ }^{1}$ whole networks of of dialect corpora, often using the same tools (such as the Corpus of spoken Rusyn ${ }^{2}$ or the Ustja River Basin corpus ${ }^{3}$ ) to corpus initiatives focussing on early stages of Slavonic (such as the Tromsø Old Russian and OCS Treebank TOROT ${ }^{4}$ ), and smaller-scale corpora enabling empirical research in very particular domains (such as the Corpus of pre-standardised Balkan Slavic literature ${ }^{5}$ or the Spoken Torlak dialect corpus ${ }^{6}$ ) and non-native varieties (such as the Russian Learner Corpus) http:// www.web-corpora.net/RLC. This is yet another domain in which the peculiarities of Slavic become relevant from a larger perspective, in showing the need to complement and adjust existing tools. Indeed, the fact that the Czech National Corpus team chose to use dependencies rather than constituent structure for annotating syntax - directly inspired by the Slavists of the Prague School - is an important reason why dependency annotation is now an important standard in the field of natural language processing.

At the same time, the study of Russian and Slavic languages may also contribute to our understanding of language in general. General linguistics can only exist on the basis of very detailed and fine-grained language specific study of a single language. Furthermore, comparative study of Slavic languages has also led to important insights into language change and variation. A good example again is the work on Slavic aspect, which has been a touchstone in work on aspect cross-linguistically and a major challenge for approaching the interaction between grammar and lexicon. It does not come as a surprise that Slavic aspect plays a key role in the pioneering work by Bernard Comrie, Östen Dahl, Vladimir Plungjan, Wolfgang Klein and Carlota Smith. Furthermore, stretching over a large geographical space, covering various cultural spheres and entering into manifold contact situations, the Slavic language family provides a prime example for the challenges involved in disentangling the intricate interactions of inheritance and contact, one of the major methodological issues in contemporary linguistics. Work on the Slavic languages has thus an important role to play far beyond its family-focus.

All of this shows that there is still a lot to be discovered in Russian and the other Slavic languages, with the increasingly rich and interdisciplinary methodological inventory initiating new research questions and allowing to approach many well-known facts from new perspectives. So we are deeply convinced that Russian and Slavic linguistics matters; as editors of Russian Linguistics we are looking very forward to hosting new discoveries and exciting discussions.

We invite all people working on Slavic linguistics and general linguistics from all different theoretical backgrounds to consider Russian Linguistics as a relevant, vibrant and inspiring platform to publish their work on Russian and Slavic linguistics. While, fortunately, it is no longer necessary for Russian Linguistics to function as an "okno na zapad" (Comtet, van Holk, Lehfeldt 1996, p. 1), it continues to keep its eyes open and provide windows into the diverse aspects of Russian and the Slavic languages and the diversity of perspectives on their description. As editors, we aim to do our best to continue the founding editor's objective, "to provide a basis for the exchange of opinions and the development of new ideas" (Editorial 1974, p. 1).

\footnotetext{
${ }^{1}$ http://parasolcorpus.org.

2 www.russinisch.uni-freiburg.de/corpus.

3 www.parasolcorpus.org/Pushkino.

${ }^{4}$ https://torottreebank.github.io/.

${ }^{5}$ http://hdl.handle.net/11356/1368.

${ }^{6} \mathrm{http}: / /$ hdl.handle.net/11356/1281.
} 
Publisher's Note Springer Nature remains neutral with regard to jurisdictional claims in published maps and institutional affiliations.

\section{References}

Comtet, R., van Holk, A. G. F., \& Lehfeldt, W. (1996). Russian linguistics before and after. Russian Linguistics, 20(1), 1-2. https://doi.org/10.1007/BF02529831.

Editorial (1974). Russian Linguistics, 1(2), 1-2. https://doi.org/10.1007/BF02528236.

Schweier, U. (2014). The 40th anniversary of Russian Linguistics. Russian Linguistics, 38(2), 257-259. https://doi.org/10.1007/s11185-014-9132-3. 